\title{
Sustained and Balanced Investment in Research \& Innovation is Critical to U.S. Competitiveness
}

\author{
Prem S. Paul, D.V.M., Ph.D.
}

Vice Chancellor for Research \& Dean of Graduate Studies

University of Nebraska-Lincoln

$\mathrm{T}$ he United States' leadership in the global economy since the 1950s has been the envy of the world. This leadership has been achieved through technological innovation resulting from significant investments in research and development (R\&D). The majority of the R\&D investment, especially for fundamental research, has been made through the federal agencies. These investments in fundamental research have paid big dividends and led to the development of innovative technologies and have been exploited to generate new and expanded commerce.

The new economy is just one example of the mega-benefits resulting from innovations in science and technology. People also are living longer and healthier lives as a result of discoveries in the medical sciences and the ample availability of high quality, safe food at affordable prices produced through advances in agriculture. Our success has led many other nations to adopt our model of supporting innovation. Recent indicators show that other countries have begun to invest higher shares of their gross domestic product in R\&D. At the same time, U.S. investments have been reduced and, for many federal agencies, have not kept pace with inflation. If the U.S. is to continue to compete in the new economy, it is critical that we increase our investments in fundamental research. The recent report "Rising Above the Gathering Storm: Energizing and Employing America for a Brighter Economic Future" further makes this case. $^{1}$

\section{Increased and Sustained Investment in} Research is Essential to our Future

Taking a look at the history of federal support of research and development over the past 30 years, one sees peaks and valleys in the level of federal R\&D funding (see Figure 1). These peaks and valleys represent periods of de-prioritization when other needs, such as social services, took larger shares of the federal budget, followed by an awakening to new challenges and a re-commitment to research and development. Each time our nation has been challenged, we have responded and risen to the task. Leadership for those responses has come from multiple segments of the society - U.S. Presidents, federal agencies, and the U.S. Congress have provided key leadership. The scientific community, various constituent groups and business leaders have been critical for generating discussion and new ideas, as well as for building strong support for funding initiatives. The initiatives that have the 
support of these various groups have had the highest chance for success.

TABLE 1. GDP Share Invested toward R\&D by Country/Economy for Selected Countries for Years 1998, 2001, 2002, and 2003.

\begin{tabular}{|l|l|}
\hline Country/Economy & Share (\%) \\
\hline Israel (2003) & 4.90 \\
\hline Sweden (2001) & 4.27 \\
\hline Finland (2002) & 3.46 \\
\hline Japan (2002) & 3.12 \\
\hline Iceland (2002) & 3.09 \\
\hline United States (2003) & 2.67 \\
\hline South Korea (2003) & 2.64 \\
\hline Switzerland (2000) & 2.57 \\
\hline Denmark (2002) & 2.52 \\
\hline Germany (2003) & 2.50 \\
\hline Belgium (2003) & 2.33 \\
\hline Taiwan (2002) & 2.30 \\
\hline France (2002) & 2.26 \\
\hline Singapore (2002) & 2.15 \\
\hline Netherlands (2001) & 1.88 \\
\hline Canada (2003) & 1.87 \\
\hline $\begin{array}{l}\text { United Kingdom } \\
\text { (2002) }\end{array}$ & 1.87 \\
\hline Norway (2002) & 1.67 \\
\hline Australia (2000) & 1.54 \\
\hline $\begin{array}{l}\text { Russian Federation } \\
\text { (2003) }\end{array}$ & 1.28 \\
\hline China (2002) & 1.22 \\
\hline
\end{tabular}

SOURCES: National Science Foundation, Division of Science Resources Statistics, National Patterns of R\&D Resources (annual series); OECD, Main Science and Technology Indicators (2004); Iberoamerican Network of Science and Technology Indicators, http://www.ricyt.edu.ar; and Science and Engineering Indicators 2006, http://www.nsf.gov. 
TABLE 2. Total Federal and Nonfederal support of U.S. R\&D as a share of GDP.

\begin{tabular}{|l|l|l|l|}
\hline & \multicolumn{3}{|l|}{ R\&D/GDP (\%) } \\
\hline & & $\begin{array}{l}\text { Federal } \\
\text { support }\end{array}$ & $\begin{array}{l}\text { Nonfederal } \\
\text { support }\end{array}$ \\
\hline & Total & & \\
\hline 1981 & 2.31 & 1.08 & 1.23 \\
\hline 1986 & 2.69 & 1.22 & 1.47 \\
\hline 1991 & 2.68 & 1.01 & 1.67 \\
\hline 1996 & 2.52 & 0.81 & 1.71 \\
\hline 2001 & 2.74 & 0.72 & 2.02 \\
\hline 2002 & 2.64 & 0.74 & 1.90 \\
\hline 2003 & 2.63 & 0.76 & 1.87 \\
\hline 2004 & 2.56 & 0.76 & 1.80 \\
\hline 2005 preliminary & 2.59 & 0.76 & 1.83 \\
\hline 2006 preliminary & 2.60 & 0.73 & 1.86 \\
\hline
\end{tabular}

\section{GDP=gross domestic product}

$R \& D=$ research and development.

SOURCES: Department of Commerce, Bureau of Economic Analysis, special tabulations, 2004; Office of Management and Budget, special tabulations, 2004; and National Science Foundation, Division of Science Resources Statistics, special tabulations, 2007. Derived from Table 13, National Science Foundation Division of Science Resources Statistics, 2007.

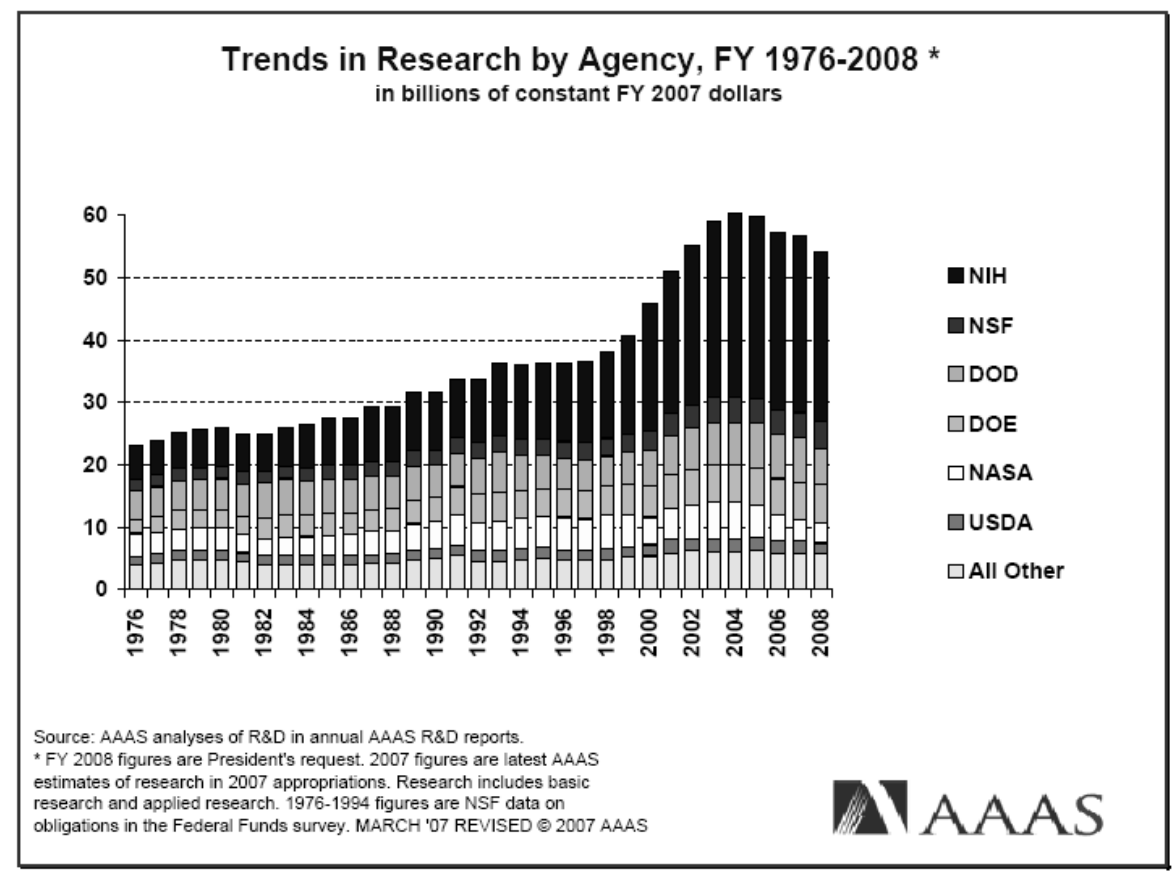

Trends in Research by Agency, FY 1976-2008 (Source: AAAS, 2007, see website Figure 1. http://www.aaas.org/spp/rd/trres08p.pdf). 


\section{Federal R\&D Support History}

Federal support for R\&D can be grouped into four major eras:

- The Vannevar Bush Era, resulting in the establishment of the National Science Foundation

- The Post-Sputnik Space Race, resulting in the establishment of the National Aeronautics and Space Administration, the Defense Advanced Research Projects Agency and the National Defense Education Act in 1958

- The doubling of NIH Research funding from 1998-2003

- The Current Era: The American Competitiveness Initiative in 2006

\section{Vennaver Bush Era}

Following World War II, President Franklin Roosevelt gave a charge to the Honorable Vennaver Bush in a Nov. 14, 1944 letter $^{2}$ that is still appropriate and is an excellent example of presidential leadership. President Roosevelt said, "New frontiers of the mind are before us and if they are pioneered with the same vision, boldness and drive with which we waged this war we can create a fuller and more fruitful employment and fuller and more fruitful life." As a result of the presidential initiative, Vennaver Bush prepared a report ${ }^{2}$ that had an enormous impact. He outlined the following five fundamentals in his report:

1. "Stability of Support. Whatever the extent of support may be, there must be stability of funds over a period of years, so that long range programs may be undertaken.
2. Advisory Boards. The agency to administer such funds should be composed of citizens selected only on the basis of their interest in and capacity to promote the work of the agency.

3. External Grants. The agency should promote research through grants and contracts to organizations outside the federal government. It should not operate laboratories on its own.

4. Conduct of Basic Research by Universities without interference from Federal Government. Support of basic research in the public and private colleges and universities must leave internal controls of policy, personnel, and method of scope of research to institutions themselves.

5. Accountability of Research. While assuring complete independence and freedom for the nature and scope and methodology of research carried on, the institution must be responsible to the President and Congress. "

As a result of Mr. Bush's report, the National Science Foundation (NSF) was established in 1950 and has been a great success story. The NSF has supported fundamental research leading to major discoveries and today is the largest source of funding for physical sciences, engineering, social sciences and environmental sciences research.

\section{Post-Sputnik Era}

The nation was challenged again with a loss in the space race when the Soviets launched Sputnik I on October 4, 1957 and Sputnik II on Nov. 7, 1957 (see 
reference 3 on Association of American Universities website for sputnik timeline). The U.S. responded on Nov. 21, 1957 with President Eisenhower's appointment of James Killian as the first Science Advisor to the President and the establishment of the President's Science Advisory Committee. The Defense Advanced Research Projects Agency was formed on February 7, 1958, and President Eisenhower signed the National Aeronautics Space Administration Act on July 29, 1958 to establish NASA. The President also signed the National Defense and Education Act supporting mathematics and science education that help prepare the U.S. workforce for the next fifty years.

These initiatives and the support of the Congress resulted in increased funding for fundamental research and $R \& D$ in general. Funding for the National Science Foundation increased from $\$ 34$ million in 1958 to $\$ 500$ million in 1968. Similarly, funding for NIH grew from $\$ 210$ million in 1958 to $\$ 1.08$ billion in $1968^{3}$.

These investments and the vision of Vannevar Bush carried U.S. R\&D through the late 1990s, but new vision and leadership were needed for the next decade. Representative Vernon Ehlers' 1998 editorial "The Future of Science Policy" captures this need well ${ }^{4}$. "Although the U.S. Science and Technology enterprise has achieved enormous success, it is essentially operating on autopilot. The policies that Vennaver Bush outlined in his 1945 report - Science - The Endless Frontierstill to a large extent guide the research enterprise. The context in which S\&T presently operates has changed remarkably." He challenged the nation to set priorities for the science agenda and asked for input.

In more recent times, Congress and the President supported doubling of the National Institutes of Health (NIH) budget from 1998 to 2003, with increases of $15 \%$ per year. This was accomplished with the leadership and support of patient advocates, scientific and university associations, the U.S. Congress and the President. Unfortunately, the NIH budget has not increased since the doubling, but has flattened and actually decreased when adjusted for inflation.

\section{Sustained and Balanced Support for R\&D}

Although the doubling of $\mathrm{NIH}$ funding addressed the needs of medical research from 1998-2003, funding for the physical sciences and engineering suffered. This time, the stimulus for reawakening the nation was the report "Rising Above the Gathering Storm: Energizing and employing America for a Brighter Economic Future" prepared by the National Academies of Science ${ }^{1}$. This report was prepared at the urging of Sen. Lamar Alexander and Sen. Jeff Bingaman of the Committee on Energy and Natural Resources, with the support of Rep. Sherwood Boehlert and Rep. Bart Gordon of the House Committee on Science. They asked the National Academies to define "what top 10 actions policy makers should take to enhance the science and technology enterprise so the U.S. can successfully compete, prosper and be secure in the global community of the 21st century"1. 
This is an excellent example of leadership arising from multiple segments of society, including the business community, the U.S. Congress and the President. The report suggested that we are not keeping up with other countries, that we must invest in developing our talent base in science, mathematics and engineering, and that we must support fundamental research, which is the key to innovation. The report $^{1}$ also stated that four criteria are critical in attracting and retaining the multinational corporations that create jobs: research and innovation talent, the availability of a qualified workforce, the quality of research universities, and federal support for research and development.

The report stated: "Although the U.S. economy is doing well today, current trends in each of those criteria indicate that the United States may not fare as well in the future without government intervention. This nation must prepare with great urgency to preserve its strategic and economic security. Because other nations have, and probably will continue to have, the competitive advantage of a low wage structure, the United States must compete by optimizing its knowledgebased resources, particularly in science and technology, and by sustaining the most fertile environment for new and revitalized industries and the wellpaying jobs they bring. We have already seen that capital, factories, and laboratories readily move wherever they are thought to have the greatest promise of return to investors." 1
The four recommendations of "Rising Above the Gathering Storm"1 were:

"1. Focus on actions in K-12 education (10,000 Teachers, 10 Million Minds). Increase America's talent pool by vastly improving K-12 science and mathematics education.

2. Research (Sowing the Seeds) Sustain and strengthen the nation's traditional commitment to long-term basic research that has the potential to be transformational, to maintain the flow of new ideas that fuel the economy, provide security, and enhance the quality of life.

3. Higher Education (Best and Brightest). Make the United States the most attractive setting in which to study and perform research so that we can develop, recruit and retain the best and brightest students, scientists and engineers from within the United States and throughout the world.

4. Economic Policy (Incentives for Innovation). Ensure that the United States is the premier place in the world to innovate; invest in downstream activities such as manufacturing and marketing; and create high-paying jobs based on innovation by such actions as modernizing the patent system, realigning tax policies to encourage innovation, and ensuring affordable broadband access."

This report has been enthusiastically received and has had enormous impact in awakening the U.S. to the need for additional investments in R\&D. The American Competitive Initiative was launched by President Bush in 2006 with 
the promise of doubling funding for the NSF, DOE Office of Science, and the National Institute of Standards and Technology. Congress also has embraced the recommendations of the report.

While it is exciting that there is long-overdue strong support for the physical sciences and engineering, funding for NIH has not kept up with inflation since the doubling was completed. The proposed NIH budget for FY08 is $\$ 28.8$ billion. If enacted, this will be $7.4 \%$ below the 2004 highest level after adjusting for inflation, according to Koizumi, $2007^{5}$. Heinig et al. ${ }^{6}$ report that the NIH budget for the past five years has been flat and real purchasing power is $13 \%$ below that of 2003 , and argue that $\mathrm{NIH}$ be provided $3 \%$ to $4 \%$ increases after adjustment for inflation.

Department of Defense R\&D funding also is not keeping up with DOD needs, according to a memo by John Young, Director of Defense Research and Engineering and Acting Undersecretary of Defense for Acquisition, Technology, and Logistics, who believes that the Defense S\&T program should be expanded by $\$ 10$ billion over five years to "keep pace with emerging threats" ${ }^{\prime \prime}$.

These suggested initiatives emphasize the need for increased investments in R\&D in order for the U.S. to remain globally competitive.

\section{A Balanced Portfolio}

It is critical that the funding portfolio be balanced across various disciplines, between single investigators and multidisciplinary teams, between federal national laboratories and academic institutions, and across geographical regions of the United States. This helps ensure that solutions to global challenges are accomplished in a timely manner, are well accepted by society, and that talented people throughout the United States are engaged in addressing these issues.

Currently, support for various disciplines is uneven, and federal funding for the social sciences, humanities and arts is especially low (see Tables $3 \& 4$ ). Distribution of total $R \& D$ as well as federal $R \& D$ obligations is disproportionate amongst states. It is critical for our future that all states are actively engaged in R\&D innovation and that young people throughout the U.S. have an opportunity to be benefit from these investments. Currently, more than $50 \%$ of total Federal R\&D funding is obligated in six states (see Table 5). This disparity is not explained by population differences alone. The EPSCoR/IDeA states have about $20 \%$ of the population, and $18 \%$ of academic scientists and engineers who are engaged in research (Source: Data from NSF's Division of Science Resources Statistics, 2006, -Rolf Lehming). Fortunately, Congress initiated the Experimental Program to Stimulate Competitive Research (EPSCoR) in 1978 to build capacity and infrastructure and better position underfunded states to compete for federal R\&D. The program has been so successful that congress expanded this program beyond the National Science Foundation to the Department of Energy, Department of Defense, and US Department of Agriculture, EPA, and NASA. A similar program also was initiated at the National Institutes of 
Health and first funded in 1993 and is referred to as the Institutional Development Award program (IDeA). The IDeA program is now the largest such program, with more than $\$ 220$ million in funding and has two primary programs - Centers of Biomedical Research Excellence (COBRE) and the Biomedical Research Infrastructure Network (BRIN), which has now been transformed into the Integrated Networks of Biomedical Research
(INBRE). Information about the EPSCoR program can be found at: (http://www.nsf.gov/od/oia/programs/e pscor/about.jsp). IDeA program information can be found at http://www.ncrr.nih.gov/research infras tructure/institutional development awa rd/. The federal-wide EPSCoR/IdeA investment has been highly successful in building research infrastructure and has contributed to research capacity in 23 states.

Table 3: R\&D Expenditures in Science and Engineering Fields FY2005

\begin{tabular}{|l|l|l|}
\hline Discipline & $\begin{array}{l}\text { Total from all } \\
\text { sources (Millions) }\end{array}$ & $\begin{array}{l}\text { Federal R\&D } \\
\text { obligations } \\
\text { (Millions) }\end{array}$ \\
\hline $\begin{array}{l}\text { Computer } \\
\text { Sciences }\end{array}$ & 1,406 & 1,023 \\
\hline $\begin{array}{l}\text { Environmental } \\
\text { Sciences }\end{array}$ & 2,546 & 1,725 \\
\hline Life Sciences & 27,603 & 17,691 \\
\hline $\begin{array}{l}\text { Mathematical } \\
\text { Sciences }\end{array}$ & 495 & 346 \\
\hline $\begin{array}{l}\text { Physical } \\
\text { Sciences }\end{array}$ & 3,704 & 2,674 \\
\hline Psychology & 826 & 611 \\
\hline Social Sciences & 1,675 & 691 \\
\hline Engineering & 6,728 & 4,116 \\
\hline
\end{tabular}

Source: National Science Foundation/Division of Science Resource Statistics. Survey of Research and Development Expenditures at Universities and Colleges, FY2005. 
Table 4: R\&D Expenditures in Nonscience Areas for the FY2005

\begin{tabular}{|l|l|l|}
\hline Discipline & $\begin{array}{l}\text { All Sources } \\
\text { (Millions) }\end{array}$ & $\begin{array}{l}\text { Federal } \\
\text { Obligations } \\
\text { (Millions) }\end{array}$ \\
\hline $\begin{array}{l}\text { Business \& } \\
\text { Management }\end{array}$ & 1,750 & 764 \\
\hline $\begin{array}{l}\text { Communications, } \\
\text { Journalism \& } \\
\text { Libraries }\end{array}$ & 75 & 26 \\
\hline Education & 761 & 426 \\
\hline Humanities & 194 & 58 \\
\hline Law & 62 & 27 \\
\hline Social Work & 87 & 26 \\
\hline $\begin{array}{l}\text { Visual \& Performing } \\
\text { Arts }\end{array}$ & 42 & 4 \\
\hline Others & 309 & 145 \\
\hline
\end{tabular}

Source: National Science Foundation/Division of Science Resource Statistics. Survey of Research and Development Expenditures at Universities and Colleges, FY2005.

\section{Strong Universities as well as National Labs}

While it is essential that federal investment in national laboratories remains strong, it is critical that funding between federal laboratories and universities is balanced. The relative percentage of obligations of federal funding between national laboratories and universities varies by agencies. At NSF, approximately $79 \%$ of the R\&D budget goes to colleges and universities (8). At NIH, more than $80 \%$ of funding goes to universities (6). The Department of Energy Office of Science provides more than two-thirds of the funding to national laboratories. At the Department of Defense (9), basic and applied research is performed by DOD labs $(32 \%)$, industry $(40 \%)$, and universities and colleges $(21 \%)$. DOD is the third largest federal sponsor of academic research, behind NIH and NSF.
In conclusion, we as a nation need to continue to provide sustained investment for $R \& D$ to ensure long-term prosperity and global competitiveness. These investments need to be balanced across various disciplines and geographic regions to ensure that all of our available talent is engaged in the research and innovation necessary for us to compete successfully in the global economy.

\section{Disclaimer and Acknowledgements:}

This paper represents the views of the author and not necessarily of the University of Nebraska-Lincoln. The author is grateful to Ms. Monica Norby, Mr. Joel Brehm, Mr. Nathan Meier and Mr. Michael Zeleny for their help with this article. My appreciation to Dr. Koizumi, American Association for the Advancement of Science for making Fig. 
1 on the history of R\&D funding available.

\section{References Cited}

1. Committee on Prospering in the Global Economy of the 21st Century: An Agenda for American Science and Technology, National Academy of Sciences, National Academy of Engineering, and the Institute of Medicine. 2006. "Rising Above The Gathering Storm: Energizing and Employing America for a Brighter Economic Future." Washington, D.C.: National Academies Press.

2. Bush, Vannevar. 1945. "Science The Endless Frontier: A Report to the President by Vannevar Bush, Director of the Office of Scientific Research and Development." Washington, D.C.: Government Printing Office. Available online at: http://www.nsf.gov/od/lpa/nsf50/vbush1945.ht $\underline{\mathrm{m}}$.

3. Association of American Universities. 2007. "The Year After Sputnik: U.S. Response 1957 - 1958." Available online at: http://www.aau.edu/education/Sputnik_Timeli ne_2007-09-20.pdf.
4. Ehlers, Vernon J. 1998. "The Future of U.S. Science Policy." Science, 279: 302.

5. Koizumi, Kei. 2007. "National Institutes of Health in the FY 2008 Budget." In AAAS Report XXXII: Research and Development FY 2008. AAAS Intersociety Working Group. Available online at: http://www.aaas.org/spp/rd/rd08main.htm.

6. Heinig, Stephen J., Krakower, Jack Y., Dickler, Howard B., and Korn, David. 2007. "Sustaining the Engine of U.S. Biomedical Discovery." New England Journal of Medicine, 357: 1042-1047.

7. Young, John. 2007. Department of Defense Memo: "Department of Defense Science and Technology Program." Available online at: http://www.aau.edu/budget/DoD_SnT_Memo_ 2007.pdf.

8. Scott, Amy and Smith, Tobin. 2007. "National Science Foundation in the FY 2008 Budget." In AAAS Report XXXII: Research and Development FY 2008. AAAS Intersociety Working Group. Available online at: http://www.aaas.org/spp/rd/rd08main.htm.

9. Koizumi, Kei. 2007. "R\&D in the FY 2008 Department of Defense Budget." In AAAS Report XXXII: Research and Development FY 2008. AAAS Intersociety Working Group. Available online at: http://www.aaas.org/spp/rd/rd08main.htm 